\title{
Emotional intelligence in higher education: Perspectives of Nepalese college students
}

Bhawana Shrestha, MA

afk034@westcliff.edu

\begin{abstract}
This paper explores the perspective of college students regarding emotional intelligence in higher education. A great number of changes in the education system globally has developed new expectations for teachers. These days, teachers are not just the authority in a classroom but a mentor. Thus, emotions play a significant role in the teaching and learning process. This paper argues that mastery in subject matter does not make the best teacher in the eyes of students, rather emotional intelligence does. Emotional intelligence is neither the opposite of intelligence nor just the battle between mind and heart but it is the unique intersection of both. Quantitative research was done with 201 college students from different educational backgrounds. The data was analyzed with the theoretical modality influenced by Daniel Goleman's 'Emotional Intelligence' method. The first part of the research explores what aspects of teacher's students associate with being the best, and the second portion explores what behaviors the students want in their teachers in general. This research helps to identify emotional intelligence, a new domain introduced in the teaching and learning process, as significant, even from the student's perspective.
\end{abstract}

Keywords: Emotional Intelligence, higher education, teaching-learning, perspectives 


\section{Introduction}

Teaching is an art. Effective teachers use various techniques to help their students excel at whatever they are sharing because there is no single and universal approach that fits every situation. Teachers need to incorporate a variety of teaching strategies that support intellectual development, foster a mutual learning environment, and value differences in the classroom. However, with the advent of new technologies, the question becomes: if you can Google it, why teach it? Levasseur (2012) expanded upon this mentioning that "All computing devices - from laptops to tablets to smartphones- are dismantling knowledge silos and are therefore transforming the role of a teacher into something that is more of a facilitator and coach". In this context, an important question is arising in the field of education. Is the mastery of content enough for a teacher to possess in order to ensure the academic achievement of their students?

With the advancement of technology in the 21st century, life has changed a lot and so has the area of teaching. These days, we give emphasis to how we learn rather than what we learn. Research is being done about how to best support the development of an educational system that helps and motivates a child to learn more efficiently. Present day pedagogy demands teachers, students, and parents to mull over their learning strategy and engage with it both inside and outside of the classroom. With the increasing challenges and added pressure in life, learners need to be flexible, adaptable and emotionally intelligent. That means it is important for a teacher to be able to develop their skills specifically in communication, selfmanagement, teamwork, and co-operation.

Vygotskij and Cole (1981) noted that social interaction plays a fundamental role in the development of cognition and that everything is learned on two levels. The first is through interaction which then integrates into the individual's mental structure, and the second is through the path of technology integration in education. The integration of technology can both be seen as a disruption and an opportunity. However, in this era, pedagogy demands teachers to be creative in their attitudes, flexible in their approaches, and always up to date in their fields. Simultaneously, they are asked to be capable of recognizing the value of human potential, understanding the diverse needs of learners, and enriching the educational 
environment to foster their growth. Thus, present-day pedagogy demands a teacher be well equipped both with emotional as well as cognitive competencies.

\section{Discussion}

Emotional Intelligence

Emotional intelligence has become a popular phrase in recent times. Plato had once said that "All learning has an emotional base" ("The importance of emotional intelligence in training," 2014, para. 1). Emotions have great power and they enable an individual to cope with circumstances which demand the utmost efforts for survival or success. According to Salovey (2007), emotions and feelings are interwoven with the networks of reason and there is interconnectivity between emotions and cognition. Emotional intelligence is neither the opposite of intelligence nor the triumph of heart-over-head, but it is the unique intersection of both.

Daniel Goleman (2010), an American psychologist, elaborated on the idea of "Emotional Intelligence" in 1995 by highlighting the fact that anxiety, anger, and depression hamper learning. These emotions put people into a state where they cannot take in information efficiently. Additionally, Goleman (2010) expressed that an emotionally intelligent teacher can bring a different insight into the classroom. There is an example a four-year-old child named Judy who seemed to be a wallflower among her more gregarious playmates. She was found hanging back from the action at playtime, staying on the margins of games while her friends were plunging into the center. It was found later that she was actually a keen observer, when one of her teachers asked her to put each girl and boy in the part of the room they liked to play in most and to identify which children each boy and girl liked to play with the most, she was able to do it without a problem (Goleman, 2010).

A teacher's self-efficacy and empathy are seen as an important quality that he/she should possess to be both effective and efficient in their teaching. Emphasis has been placed on a teacher's ability to develop their emotional intelligence as there has been an identified link between emotional intelligence and learning. However, less has been discovered from the student's perspective. The question arises as to whether students prefer emotionally intelligent teachers or not. How do they perceive teachers who demonstrate self-efficacy and empathy in 
their teaching, classroom management and interaction with their students from those who do not?

A teacher's actions and decision making abilities in the teaching-learning process holds specific significance. Research has suggested that there is a relationship between feeling and decision making. Grewal and Salovey (2005) suggest that emotional intelligence is the ability to monitor one's own and other's feelings, to discriminate among them and to use this information to guide one's thinking and actions. Grewal and Salovey (2005) also suggest that decisions are based not only on assessing outcome, but also on the basis of the emotional quality associated with it.

Goleman (2010) notes that teachers who are emotionally intelligent are more effective as they are aware of how their actions and decisions influence the learning and behavior of their students. Emotional intelligence has four dimensions: perceiving, facilitating, understanding, and managing emotions. If a teacher is aware of these four domains, they have the ability to process abstract thoughts and navigate them properly by adapting to the various settings. Research suggests that the synchronization between teachers and students is important to build rapport in the classroom and that synchrony is based on the coordination of the movement between them (Bernieri, Janet, Rosenthal, \& Knee, 1994). This study correlated the friendliness, happiness, enthusiasm, interest, and easygoing attitude of the teachers with the how their students felt in the class. The understanding of this connection is the basic skill associated with emotional intelligence (Bernieri, Janet, Rosenthal, \& Knee, 1994).

What is the mark of a good teacher? Individuals at school have emotions; they think and feel. Though teaching is still considered as an honorable profession, it is also the profession where scrutiny is undeniable. Today, teachers are not just seen as the facilitators and instructors but also as role models and motivators. Darling-Hammond (2003) mentions that the classroom teacher is the most influential variable influencing student achievement outside of the child's home environment.

McNulty and Quaglia (2007), in their work with the International Center for Leadership in Education, examined some of the most successful high schools noting that "in addition to the achievement gap, there is a participation gap, which is characterized by students who feel 
unwelcome, disconnected and lost in our schools" (McNulty \& Quaglia, 2007). McNulty and Ouaglia (2007) found that the schools they examined had the challenges of poverty, mobility, and diversity but still had high rates of student success, which they believed was due to the type of relationship the teachers were able to form with the students. Though research has been conducted to help find what affects the student's learning challenges less priority has been given to the students' moral and social well-being and the establishment of positive relationships with people around them. In this scenario, the prioritization of the classroom teachers to recognize and manage emotional intelligence (EI) could help make the necessary connection between students and their various educational needs and backgrounds. Various research and publications have shown how emotional intelligence can be transpired in learning and how the teachers can play their part. However, less is known from the student's perspective regarding whether students prefer emotionally intelligent teachers or not. With this in mind, the purpose of my study was to find out how much importance a student gives to the emotional intelligence of his/her teacher. Specifically, the study focused on the following questions:

1. When it comes to choosing best teachers, what do the students prefer: emotionally intelligent teachers or teachers with content mastery?

2. What do students of the present context want from their teachers in general? How do they perceive their teachers?

This study was conducted from April 2017 to June 2017 with students studying in both public and private colleges in Kathmandu. The students are affiliated with different universities. Specifically, the study included students from the Institute of Advanced Communication, Education and Research (Pokhara University, Nepal), King's College (Westcliff University), Sandipani Multiple College (Tribhuvan University), Kathmandu Engineering College (Tribhuvan University), Nepal Medical College (Kathmandu University), Tribhuvan University Central Department of Management (Masters in Finance and Control), Samanta Foundation Nepal, and Smart Club.

The population of this research was the higher-level students studying at the colleges and Universities of Kathmandu Valley. The respondents included two hundred and one high school, 
undergraduate, graduate, and postgraduate students. As the target population was from four different educational levels, the researcher set the number with the intention of having an equal number of people from all the levels.

Of the total respondents, $113(56.2 \%)$ were male and 88 (43.5\%) were female. The student population from which the response was drawn included 26 (12.9\%) high school students, 101 (50.2\%) undergraduate students, 29 (14.4\%) graduate students, and 45 (22.4\%) postgraduate students.

Twenty questions in the form of short sentences using 5-point Likert scale were formed with reference to Daniel Goleman's (2010) identified areas of emotional intelligence. These areas included one's ability to be self-aware, which is defined as knowing one's emotions, strengths, weaknesses, values and goals and recognizing their impact on others while using gut feelings to guide decisions. The second is one's ability to self-regulate, which is defined by managing or redirecting one's disruptive emotions and impulses and adapting to changing circumstances. The third is regarding social skills, in specific the ability to manage other's emotions to move people in the desired direction. The fourth is the ability to empathize, meaning to recognize, understand, and consider other people's feelings especially when making decisions. Lastly, the ability to motivate, specifically to motivate oneself to achieve for the sake of achievement. (Goleman, 2010)

The questions were divided into two groups with ten questions each. The first set of questions asked the respondents to mull over the features of their current best teacher, while the second set asked them to identify features they would like to see in their teachers in general. The questions were framed following the guidelines of the emotional quotient Inventory (EQ-i). Mae Hapal (1997), a researcher in the psychology department at the Polytechnic University in the Philippines, stated that "The emotional quotient Inventory (EQ-i) is the first scientifically validated and most widely used emotional intelligence assessment in the world. Based on more than 20 years of research worldwide, the EQ-i examines an individual's social and emotional strengths and weaknesses" (Goleman, 2010). 
In analyzing the results, the average mean of each question was reported and on the basis of that, the scores were evaluated to better understand the outcome. Two different tables were prepared to compare the scores of two different groups of the questionnaire.

\section{Table 1}

Students' Perception on Their Best Teacher's Traits

\begin{tabular}{|c|c|c|}
\hline S. $\mathbf{N}$ & Statements & $\begin{array}{c}\text { Average } \\
\text { Mean } \\
\text { Value }\end{array}$ \\
\hline 1. & My best teacher treats every student with respect. & 4.27 \\
\hline 2. & I feel emotionally safe in his/her classroom. & 4.33 \\
\hline 3. & He/she empathizes me. & 3.80 \\
\hline 4. & $\begin{array}{l}\mathrm{He} / \text { she prioritizes on knowledge of the subject rather than on } \\
\text { delivery in the classroom. }\end{array}$ & 3.00 \\
\hline 5. & I feel like I belong (accepted and liked) at his/her classroom. & 4.10 \\
\hline 6. & I can get along with my best teacher. & 4.16 \\
\hline 7. & My best teacher gets along with the students well. & 4.12 \\
\hline 8. & $\begin{array}{l}\text { My best teacher takes account of my emotional reactions to } \\
\text { the lesson he/she has taught. }\end{array}$ & 3.70 \\
\hline 9. & $\begin{array}{l}\text { My best teacher plays an important role in my academic } \\
\text { performance. }\end{array}$ & 4.28 \\
\hline 10. & $\begin{array}{l}\text { My best teacher takes care of every mistake we make and } \\
\text { teaches us not to repeat it. }\end{array}$ & 4.21 \\
\hline
\end{tabular}


Students' stated that for them the main characteristic of a best teacher is that he/she makes them feel emotionally safe in their classroom as it has the highest average mean value among all i.e., 4.33. Interestingly, the students did not focus on the content mastery of their teachers as they felt that their best teachers were more focused on delivery instead of content mastery. The importance of a teacher's content mastery received the lowest average mean among all, i.e. 3.00. However, at the same time, the students surveyed also believed that it was their best teachers who played an important role in their academic performance with the mean value of 4.28 , implying the fact that it was not the teachers' knowledge of the content rather their delivery and their other skills that resonated with the students.

Looking at it from the emotional intelligence framework, the students perceive that their best teachers have good relationship management skills as the average mean of the statements associated with it are in highest value. This proves that relationships between teachers and students do matter, particularly in those schools servicing high-risk populations (McNulty \& Quaglia, 2007). The mean value of the students who felt that they could get along with their best teachers was 4.10. Similarly, the mean value of students also felt that even other students could get along with their best teachers was 4.16. The students surveyed also found that their best teachers treated everyone equally, as this was represented by an average mean value of 4.27 .

A study conducted by Harme and Pianta (2007), found that students with significant behavior problems are less likely to have problems if their teachers are sensitive to their needs and provide frequent, consistent, and positive feedback. The research of this study concluded similar findings. The students believed that their best teacher motivated them not to recur any mistakes, which was represented by an average mean value of 4.21 .

On the other hand, the data revealed that the students perceived their best teachers as having low social awareness competence. Most of the students were not able to identify whether their best teachers took account of their emotions while teaching. The average mean value for the statement was 3.70. Similarly, the average mean value of their best teacher empathizing them was also only 3.80. From this what we can derive is that though the teachers 
lack the self and social awareness aspect embedded within emotional intelligence, what they do have is social management skills.

Students' Perspectives on Emotional Intelligence in Teaching

Table 2

Students' Perception on How Teachers in General Should be

\begin{tabular}{|c|c|c|}
\hline S.N. & Statements & $\begin{array}{l}\text { Average } \\
\text { Mean } \\
\text { Value }\end{array}$ \\
\hline 1. & $\begin{array}{l}\text { A teacher should be gentle and considerate as much as be an } \\
\text { intellectual. }\end{array}$ & 4.42 \\
\hline 2. & $\begin{array}{l}\text { A teacher should feel that in his/her classroom all the } \\
\text { students are made to feel safe and accepted. }\end{array}$ & 4.65 \\
\hline 3. & $\begin{array}{l}\text { A teacher should encourage his/her students to recognize that } \\
\text { all humans deserve respect and care. }\end{array}$ & 4.69 \\
\hline 4. & $\begin{array}{l}\text { During instruction, a teacher should demonstrate his/her } \\
\text { students that everyone's opinion is valuable and should be } \\
\text { respected. }\end{array}$ & 4.54 \\
\hline 5. & $\begin{array}{l}\text { A teacher should be able to create a sense of belonging } \\
\text { among his/her students. }\end{array}$ & 4.40 \\
\hline 6. & $\begin{array}{l}\text { A teacher should feel that students can contribute very little } \\
\text { to learning in his/her classroom. }\end{array}$ & 2.40 \\
\hline 7. & $\begin{array}{l}\text { A teacher should be able to make a significant difference in } \\
\text { the lives of his/her students. }\end{array}$ & 4.05 \\
\hline
\end{tabular}




\begin{tabular}{|c|l|l|}
\hline 8. & $\begin{array}{l}\text { A teacher should shout at his/her students as soon as they } \\
\text { make him angry. }\end{array}$ & 2.00 \\
\hline 9. & $\begin{array}{l}\text { A teacher should use emotionally inclined teaching materials } \\
\text { when teaching. (e.g, stories about pets, friends etc.) }\end{array}$ & 4.13 \\
\hline 10. & $\begin{array}{l}\text { A teacher should listen to ideas from his/her students to help } \\
\text { facilitate learning in his/her classroom. }\end{array}$ & 4.66 \\
\hline
\end{tabular}

Table 2 reveals what a student perceives to be the essential traits of a teacher. The most important factor the student surveyed identified is that the teacher should be socially aware. The highest average mean value was in regard to the teacher being empathetic at 4.69. Similarly, the students also wanted their teachers to have the component of self-management, as they felt that the teachers should not show his/her anger as soon as the students provoked them. This category received the lowest average mean value of all at 2.00. According to Bar-On (2007), being able to manage personal, social, and environmental change by coping with the immediate situation and solving problems of an interpersonal nature are the traits of emotionally intelligent people. Students identified wanting their teachers to have this trait, which is further supported by a study on teacher self-efficacy, which showed there is a link between teachers with higher emotional intelligence and teacher self-efficacy in the ability to manage their classroom, and motivate students (Fabio \& Palazzeschi, 2008).

The students surveyed believed that teaching-learning is a collaborative approach, thus the content mastery of the teacher would not come into effect if he/she was not able to integrate the knowledge of the students in the classroom. Students who identified those teachers who have expressed their perception of low potential for student contribution was low; the average mean was 2.40. Whereas students seemed to believe that a teacher should listen to ideas from his/her students to help facilitate learning in his/her classroom, as the average mean value of this statement was 4.66 . The students perceived that teachers play a significant role in their lives and thus, should be able to create a sense of belonging among their students. Comparative Analysis 
The overall data comparison for this study revealed that the teachers who students perceive as their best teachers currently are recognized by their students as someone who is high-functioning in terms of social relationships but low-functioning in terms of self and social awareness. Ironically, these students believe that self and social awareness is the most important competence that teachers need to develop in general. Importantly, they also believe that it is the delivery, not the content, that teachers need to focus on. In this regard, their best teachers prioritize delivery rather than content mastery; however, they also lack empathy. Students seemed to perceive that their teachers need to be empathetic and have good control over their emotions. This leads to the fact that people who are currently involved in teaching also need to think about their competence in emotional intelligence.

\section{Conclusion}

On the basis of this research, it can be concluded that students prefer to have an emotionally intelligent teacher rather than a teacher who only understands the content. Emotional intelligence focuses on the person-centered process for teachers. The students get to learn by building human development behaviors. The emotionally intelligent teachers are active in their orientation to students, work, and life which makes them resilient even when the environment is negative in their classroom. Students perceive this as a highly significant value when it comes to their learning. Students choose their best teachers, not on the basis of their academic qualifications, but rather on the basis of the traits they project in the classroom. An emotionally intelligent teacher devotes plenty of energy to creating an encouraging atmosphere in the classroom and takes into account the learners' feelings. Students perceive this as an important component when they consider their best teachers. Students feel that even if their teachers may be the master of their content, if they do not devote their energy in relationship building with their students, they cannot bring any significant change. These students perceived that even their academic performance highly relies on the relationship they have with their best teachers. When it comes to relationship building, maintaining a higher level of emotional intelligence is important as this helps teachers to have a better interaction with students. 
Regarding the second research question, the surveyed students' responses proved that they want every teacher to be emotionally intelligent. Emotional intelligence is the ability to understand expressions of emotions in oneself and others. This signifies that students want every teacher to be resilient and calm when it comes to handling their stress by being aware of the environment around them. The surveyed students expressed that they wanted their teachers to calmly listen to them by knowing their own expectations first and then that of their students. Students associated their teachers with their devotion to learners, enthusiasm in the teaching process, approach to their profession, and ability to establish a harmonious relationship with their students.

The question posed through this study facilitated an inquiry into emotional intelligence as a possible indicator from the perspective of the students. Interpersonal relationship management, self-actualization, and stress management are some of the important skills teachers need to possess beyond their mastery in content. However, additional research is required and recommended because with limited resources the opinions of this study were only collected from the colleges of Kathmandu. 


\section{REFERENCES}

Bar-On, R., Maree, K., \& Elias, M. J. (2007). Educating people to be emotionally intelligent. Westport, CT: Praeger.

Bernieri, F. J., Davis, J. M., Rosenthal, R., \& Knee, C. R. (1994). Interactional synchrony and rapport: Measuring synchrony in displays devoid of sound and facial Affect. Personality and Social Psychology Bulletin, 20(3), 303-311. doi:10.1177/0146167294203008

Darling-Hammond, L. (2003). Keeping good teachers: Why it matters, what leaders can do. Educational leadership: journal of the Department of Supervision and Curriculum Development, N.E.A, 60(8), 6-13. Retrieved from http://www.ascd.org

Fabio, A. D., \& Palazzeschi, L. (2008). Emotional intelligence and self-efficacy in a sample of Italian high school teachers. Social Behavior and Personality: an international journal, 36(3), 315-326. doi:10.2224/sbp.2008.36.3.315

Grewal, D., \& Salovey, P. (2005). Feeling smart: The science of emotional intelligence. American Scientist, 93(4), 330. doi:10.1511/2005.4.330

Helm, C. (2007). Teacher dispositions affecting self-esteem and student performance. The Clearing House: A Journal of Educational Strategies, Issues and Ideas, 80(3), 109-110. doi:10.3200/tchs.80.3.109-110

Lvasseur, A. (2012). Teaching innovation is about more than iPads in the classroom. Retrieved from http://mediashift.org

McNulty, R. J., \& Quaglia, R. J. (2007). Rigor, relevance and relationships. School Administrator, 64(8), 18-23.

Salovey, P. (2007). Emotional intelligence: key readings on the Mayer and Salovey model. Port Chester, NY: Dude Publ.

The importance of emotional intelligence in training. (2014). Administrate. Retrieved from http://www.getadministrate.com/blog/the-importance-of-emotional-intelligence-intraining/

Vygotskiĭ, L. S., Cole, M., Stein, S., \& Sekula, A. (1978). Mind in society: The development of higher psychological processes. Cambridge, MA: Harvard University Press. 